\title{
Investor sentiment and foreign financial flows: Evidence from South Africa*
}

\author{
Hilary Tinotenda Muguto ${ }^{1}$, Lorraine Rupande ${ }^{2}$, \\ Paul-Francois Muzindutsi ${ }^{3}$
}

\begin{abstract}
Foreign financial flows to emerging markets have increasingly become important following the opening of financial markets globally. These financial flows are a function of a country's fundamentals related to future productivity. However, macroeconomic fundamentals cannot explain some of the patterns in these financial flows, especially in emerging markets. In this study, we tested whether investor sentiment can be used as an alternative explanation for the foreign financial flows in South Africa. We employed net foreign purchases of shares and bonds, and we constructed a composite investor sentiment measure using a set of proxies. We then estimated autoregressive distributed lag models - linear and nonlinear - to determine the relationship between sentiment and foreign financial flows in both the long and short run. The results showed that investor sentiment does influence foreign financial flows into South Africa. Therefore, it can be concluded that besides economic performance and stability of a country, it is of crucial importance to improve the perceived outlook for the country as to attract foreign financial flows. This finding is relevant for South Africa as a country that depends significantly on foreign capital flows to fill its widening gap between the savings and the investment needed to support enough economic growth.
\end{abstract}

Key words: Foreign financial flows, investor sentiment, ARDL, NARDL, South Africa

JEL classification: E7, G1, G3, G4, G28

* Received: 26-02-2019; accepted: 13-12-2019

${ }^{1}$ PhD candidate, School of Accounting, Economics and Finance, University of KwaZulu-Natal, South Africa. Scientific affiliation: healthcare equity and finance, financial markets, behavioural finance, investment analysis and development economics. Phone: +27(0)312607871. E-mail: mugutoh@ukzn.ac.za.

2 PhD candidate, School of Accounting, Economics and Finance, University of KwaZulu-Natal, South Africa. Scientific affiliation: financial markets, behavioural finance and financial risk management. Phone: +27(0)312607871.E-mail: rupandel@ukzn.ac.za.

3 Associate professor, School of Accounting, Economics and Finance, University of KwaZulu-Natal, South Africa. Scientific affiliation: financial markets, behavioural finance, financial risk management, asset pricing, time series analysis of macroeconomic variables and development economics. 


\section{Introduction}

Over the years, financial markets have experienced tremendous changes, one being the reduction of barriers to foreign portfolio flows from one market to another (Nyangoro, 2013). This financial market liberalisation has brought about phenomena such as cross-listing of firms and international portfolio diversification (Clark and Wójcik, 2007). However, the realisation of the benefits of open markets in emerging markets has been far more complicated due to the interaction of factors related to the global financial environment and specific host country factors. These issues could help explain some of the patterns seen in the financial flows amongst some countries (Resilience, 2011). Various authors (Taylor and Sarno, 1997; Evans and Hnatkovska, 2014) have attributed most these patterns to the differences in the level of integration between the developed markets and the recipient markets, variations in country-specific risk or other factors such as familiarity regarding financial reporting standards, exchange rate regimes and control policies. It is, thus, not surprising that foreign financial flows have received increased attention in the literature over the years.

The attention on foreign financial flows has generally involved the attempt to link their patterns to the economic performance of the recipient countries (Albuquerque, 2003). However, there has been no attempt to determine whether investor sentiment influences financial flows. This phenomenon refers to investors' overall attitudes and crowd psychology towards financial assets' future cash flows and risks (Baker and Wurgler, 2006). Given the evidence that investor sentiment is a proxy for risk aversion (Sayim and Rahman, 2015; French and Li, 2017), it is conceivable that it influences foreign financial flows. Accordingly, this study hypothesises that there is a significant relationship between foreign financial flows to South Africa and investor sentiment. We constructed a composite investor sentiment index using the principal component analysis technique to measure sentiment. This need to construct an index is because there is no uncontroversial and recognised sentiment measure. Subsequently, we examined the relationships between the net foreign financial flows and the constructed sentiment index using the autoregressive distributed lag model.

Certain features warranted our focus on South Africa. It has the largest and most open economy on the continent. There is also the dual listing of companies on the Johannesburg Stock Exchange and the London Stock Exchange, which means that South African financial products enjoy enormous exposure to international investors. There is a growing role of foreign investors in South Africa evidenced by the foreign equity ownership estimations of about $40 \%$ on the South African market and the foreign direct investment amounting to around 49\% of GDP (Thomas, 2017). Studies on foreign financial flows in South Africa have, however, focussed on their effect on economic growth (Adeola and Aziakpono, 2017; Agrawal, 2015; Nistor, 2015; Strauss, 2017; Sunde, 2017). The few that have investigated their determinants have focused on whether economic performance influences the 
amount of flows into the country (Kariuki, 2015; Opperman and Adjasi, 2017; Gosssel and Beard, 2019). Thus, we sought to address this gap. The findings of this research have implications for policymakers in the control of risks associated with foreign financial flows such as sudden reversals and contagion.

\section{Literature review}

The opening of markets has afforded investors the ability to move their funds in search of higher risk-adjusted returns internationally (Brennan and Cao, 1997; Coeurdacier and Guibaud, 2011; Teti et al., 2017). For recipient countries, these capital flows supplement domestic savings, which lowers the cost of capital (Stulz, 1999). Furthermore, as most economic activities are inherently risky and are prone to uncertainties, foreign financial flows provide a platform for risk-sharing. Foreign flows may also compel the development of proper regulation and instill good governance in local institutions (Errunza, 2001). Foreign portfolio flows are, however, not without inherent risks. They can be a conduit of contagion. As cross-country dependencies increase, foreign financial flows become a transmission channel through which shocks from the source country reach the recipient country (Dornbusch and Claessens, 2000; Kaminsky and Reinhart, 2000). Further, the increased dependencies on foreign financial flows to finance domestic investment may result in the displacement of the domestic savings, increased exposure to rapid reversal of investment flows, and high macroeconomic instability (Kregel, 2004).

Volatility in financial flows affects the availability and the cost of capital. This effect may spill over to the real sector as investments are disrupted (Dornbusch and Claessens, 2000). Policymakers may have to make compensatory adjustments to various policies (Eichengreen and Haussmann, 1999). Unfortunately, these adjustments are usually poorly thought out and inadequately executed. Thus, foreign flows can become a liability for the recipient economy. However, most studies that seem to have arrived at a consensus that, despite the risks that these flows pose (Dornbusch and Claessens, 2000; Errunza, 2001; Kaminsky and Reinhart, 2000), they are very beneficial to the recipient countries as they contribute to increased growth (Agarwal, 1997; Errunza, 2001; Reisen and Soto, 2001). In another light, some authors have concluded that the economic performance of the recipient countries determines the apparent patterns in foreign financial flows (Agarwal, 1997; De Santis and Lührmann, 2009). Good economic performance will attract investors that are in search of higher returns while poor economic performance can induce flight for quality.

A plausible alternative explanation for these patterns is investor sentiment. Robust economic growth and remarkable contemporaneous returns on financial markets often typify high sentiment periods (Tetlock, 2007). In such periods, sentiment- 
driven investors tend to under-assess risks, leading to significant mispricing and higher arbitrage opportunities (Stambaugh et al., 2012). The mispricing is likely to be more significant in cases where the incidence of sentiment-driven traders is high (De Long et al., 1990). Therefore, rational arbitrageurs enter the market to take advantage of the mispricing using contrarian trading strategies (Baker and Stein, 2004). For foreign investors, especially the more sophisticated smart money institutional investors (Schmeling, 2007), these arbitrage opportunities may be very significant to the extent that induces them to move their funds into the profitable market, albeit contemporaneously. All of this may occur despite the information asymmetries that they face in foreign markets that normally exacerbate home bias in their investment portfolios. As a result, foreign portfolio flows to the host country with the highly profitable arbitrage opportunities increase.

Alternatively, sentiment can influence financial flows through its impact on liquidity. Tetlock (2007) argues that high sentiment stimulates more aggressive trading from fundamental and sentiment traders, notwithstanding for different reasons. The former group enters the market to exploit arbitrage opportunities while the latter group follows the increased noise. The resulting buying and selling between these two groups increase liquidity on markets (Baker and Stein, 2004; Hui and Wang, 2014). This may explain the findings by Grossman and Stiglitz (1980) and Kyle (1985) that an increase in noise trading does not curtail market informational efficiency. Also, this reasoning is consistent with the earlier findings by Black (1986) that noise trading is pervasive and essential to the existence of liquid markets and De Long et al.'s (1990) description of noise traders as market makers. Increased liquidity lowers liquidity risk - the risk that stems from the lack of marketability of an investment that cannot be bought or sold quickly enough to prevent or minimize a loss (Pástor and Stambaugh, 2003) - and attracts more traders into the market, among them, foreign investors.

Nevertheless, there are competing reasons why high sentiment can result in reduced foreign financial flows. These include noise trader risk, the risk that noise traders' beliefs will not revert to their mean for a long time, and might become even more extreme (De Long et al., 1990). Schmeling (2007) found that sentiment increases with contemporaneous returns but mean-reverts in the subsequent period. However, the period before mean-reversion occurs cannot be accurately determined. This puts risk-averse foreign investors at risk and may result in them shunning markets with a substantial incidence of sentiment-driven investors. Limits to arbitrage ${ }^{4}$ may further inhibit the exploitation of arbitrage opportunities (De Long et al., 1990; Lee et al., 2002). Thus, primarily, the relationship between sentiment and foreign

\footnotetext{
4 The restrictions placed on funds that would ordinarily be used by rational traders to arbitrage away mispricing, which may cause prices to remain in a non-equilibrium state for protracted periods (De Long et al., 1990).
} 
financial flows depends on whether the negative sentiment impact - noise trader risk and increased volatility - outweighs the positive impact - more arbitrage opportunities and increased liquidity. It is, thus, necessary to determine the nature of the relationship between sentiment and financial flows in South Africa. Sentiment influences the functioning of markets in terms of risks and returns and should, therefore, affect the decision of where to invest.

\section{Methodology}

In this study, both the linear Autoregressive Distributed Lag (ARDL) and nonlinear ARDL models were considered to determine the interaction between investor sentiment (InvSent) and foreign financial flows of shares (NFPFS) and bonds (NFPFB). These models do not require variables to be integrated of the same order, and their estimations remain robust even when there is a single longrun relationship between variables, notwithstanding the sample size. Control variables - the interest rate (INTSR), manufacturing growth rate (MANUF), the Rand/Dollar exchange rate (RDEXR), and the returns on the All Share Index (ALSIR) - were also included as control variables in nominal terms in the model specification. Before the estimations, all the variables were tested for stationarity and unit roots using the Augmented Dickey-Fuller (ADF), Phillips-Perron (PP), and Kwiatkowski-Phillips-Schmidt-Shin (KPSS) tests to ensure that none of them were integrated of the second order. Following Pesaran et al. (2001), the ARDL model was estimated as:

$$
\begin{aligned}
\Delta y_{t}= & \beta_{0}+\sum_{i=1}^{p-1} \beta_{i} \Delta y_{t-i}+\sum_{i=0}^{q-1} \delta_{i} \Delta \operatorname{InvSent}_{t-i}+\sum_{i=0}^{q-1} \alpha_{i} \Delta \operatorname{ALSIR}_{t-i}+ \\
& +\sum_{i=0}^{q-1} \lambda_{i} \Delta E R_{t-i}+\sum_{i=0}^{q-1} \vartheta_{i} \Delta \operatorname{INTR}_{t-i}+\sum_{i=0}^{q-1} \Psi_{i} \Delta \operatorname{MANUF}_{t-i}+ \\
& +\varphi_{1} y_{t-1}+\varphi_{2} x \operatorname{InvSent}_{t-1}+\varphi_{3} \operatorname{ALSIR}_{t-1}+\varphi_{4} \text { ER }_{t-1}+\varphi_{5} \text { INTR }_{t-1}+ \\
& +\varphi_{6} \text { MANUF }_{t-1}+\mu_{t}
\end{aligned}
$$

Where: $\mathrm{y}$ is the net foreign purchase of shares and bonds, with the two equations estimated separately for the two series. $\beta_{i}, \delta_{i}, \alpha_{i}, \vartheta_{i}, \lambda_{i}$, and $\Psi_{i}$ are the short-run coefficients, $\varphi_{1}$ to $\varphi_{6}$ are the long-run coefficients, and $\mu_{\mathrm{t}}$ is the white noise term on investor sentiment and control variables. $\mathrm{p}$ and $\mathrm{q}$ are the lag lengths for the dependent and explanatory variables, respectively, determined using Schwarz Bayesian Information Criteria (SBIC) in EViews (11) with an assumption of constant and trend. Before making any inferences about the long-run relationship, model diagnostics - serial correlation, heteroscedasticity and model stability tests - were conducted. Subsequently, the F-Bounds test was conducted with a null hypothesis that the long-run coefficients are jointly equal to zero against the alternative that at least one of the coefficients is different from zero. In the case 
of the presence of a long-run relationship, an error correction model, as specified in Equation 2, is estimated to capture the short-run dynamics of the long-run relationship, such as the speed of adjustment back into equilibrium.

$$
\begin{aligned}
\Delta y_{t}= & \alpha_{0}+\sum_{i=1}^{p} \alpha_{i} \Delta y_{t-\mathrm{i}}+\sum_{i=0}^{q} \beta_{i} \Delta \operatorname{InvSent}_{t-\mathrm{i}}+\sum_{i=0}^{q} \gamma_{i} \Delta \operatorname{ALSIR}_{t-\mathrm{i}}+ \\
& +\sum_{i=0}^{q} \delta_{i} \Delta \operatorname{RDEXR}_{t-\mathrm{i}}+\sum_{i=0}^{q} \theta_{i} \Delta \operatorname{INTSR}_{t-\mathrm{i}}+\sum_{i=0}^{q} \lambda_{i} \Delta \operatorname{MANUF}_{t-\mathrm{i}}+ \\
& +\pi E C T_{t-1}+\mu_{t}
\end{aligned}
$$

Where: ECT is an error correction term that measures the speed of adjustment back to equilibrium in the cointegrating relationship between NFPFS or NFPFB and InvSent. In the case of no long-run relationship, a short-run model, as shown in Equation 3, is estimated.

$$
\begin{aligned}
\Delta y_{t}= & \alpha_{0}+\sum_{i=1}^{p} \alpha_{i} \Delta y_{t-i}+\sum_{i=0}^{q} \beta_{i} \Delta \operatorname{InvSent}_{t-\mathrm{i}}+\sum_{i=0}^{q} \gamma_{i} \Delta A L S I R_{t-\mathrm{i}}+ \\
& +\sum_{i=0}^{q} \delta_{i} \Delta R D E X R_{t-\mathrm{i}}+\sum_{i=0}^{q} \theta_{i} \Delta \operatorname{INTSR}_{t-\mathrm{i}}+\sum_{i=0}^{q} \lambda_{i} \Delta M A N U F_{t-\mathrm{i}}+\mu_{t}
\end{aligned}
$$

The ARDL model specified above implicitly assumes that the dependent variable, foreign financial flows, will respond in the same manner for both a positive or negative shock in the independent variables, investor sentiment, and the control variables. However, the relationship might be non-linear (Ghodsi, 2017). Thus, in addition to the linear ARDL, a non-linear ARDL is warranted. Following the model developed by Shin, Yu, and Greenwood (2014), the NARDL estimated herein was specified as:

$$
\begin{aligned}
\Delta y_{t}= & \beta_{0}+\sum_{i=1}^{p-1} \beta_{i} \Delta y_{t-1}+\sum_{i=0}^{q-1}\left(\delta_{1 i}^{+} \Delta \operatorname{InvSent}_{t-1}^{+}+\delta_{2 i}^{-} \Delta \operatorname{InvSent} t_{t-1}^{-}\right)+ \\
& +\sum_{i=0}^{q-1}\left(\alpha_{1 i}^{+} \Delta A L \operatorname{SIR}_{t-1}^{+}+\alpha_{2 i}^{-} \Delta \operatorname{LSIR}_{t-1}^{-}\right)+\sum_{i=0}^{q-1}\left(\lambda_{1 i}^{+} \Delta R D E X_{t-1}^{+}+\right. \\
& \left.+\lambda_{2 i}^{-} \Delta R D E X_{t-1}^{-}\right)+\sum_{i=0}^{q-1}\left(\vartheta_{1 i}^{+} \Delta \operatorname{INTSR}_{t-1}^{+}+\vartheta_{2 i}^{-} \Delta \operatorname{INSSR}_{t-1}^{-}\right)+ \\
& +\sum_{i=0}^{q-1}\left(\Psi_{1 i}^{+} \Delta M A N U F_{t-1}^{+}+\Psi_{2 i}^{-} \Delta \operatorname{MANUF}_{t-1}^{-}\right)+\varphi_{1}^{+} y_{t-1}+ \\
& +\varphi_{2}^{-} y_{t-1}+\varphi_{3}^{+} \operatorname{InvSent}_{t-1}^{+}+\varphi_{4}^{-} \operatorname{InvSent}_{t-1}^{-}+\varphi_{5}^{+} \operatorname{ALSIR}_{t-1}^{+}+ \\
& +\varphi_{6}^{-} \operatorname{ALSIR}_{t-1}^{-}+\varphi_{7}^{+} \operatorname{RDEX}_{t-1}^{+}+\varphi_{8}^{-} \operatorname{RDEX}_{t-1}^{-}+\varphi_{9}^{+} \operatorname{INTSR}_{t-1}^{+}+ \\
& +\varphi_{10}^{-} \operatorname{INTSR}_{t-1}^{-}+\varphi_{11}^{+} \operatorname{MANUF}_{\mathrm{t}-1}^{+}+\varphi_{12}^{-} \operatorname{MANUF}_{t-1}^{-}+\mu_{t}
\end{aligned}
$$

As with the ARDL model specified above, model diagnostics - serial correlation, heteroscedasticity and model stability tests - were conducted. Subsequently, the F-Bounds test was conducted with a similar null hypothesis that the long-run coefficients are jointly equal to zero against the alternative that at least one of the coefficients is different from zero. The error correction model for the NARDL in the case of the presence of a long-run relationship was specified as: 


$$
\begin{aligned}
& \Delta y_{t}=\beta_{0}+\sum_{i=1}^{p-1} \beta_{i} \Delta y_{t-\mathrm{i}}+\sum_{i=0}^{q-1}\left(\delta_{1 i}^{+} \Delta \operatorname{Inv} \operatorname{Sent}_{t-1}^{+}+\delta_{2 i}^{-} \Delta \operatorname{InvSent} \operatorname{Si-1}^{-}\right)+ \\
& +\sum_{i=0}^{q-1}\left(\alpha_{1 i}^{+} \Delta A L S I R_{t-1}^{+}+\alpha_{2 i}{ }^{-} \Delta A L S I R_{t-1}^{-}\right)+\sum_{i=0}^{q-1}\left(\lambda_{1 i}^{+} \Delta R D E X_{t-1}^{+}+\right. \\
& \left.+\lambda_{2 i}^{-} \Delta R D E X_{t-1}^{-}\right)+\sum_{i=0}^{q-1}\left(\vartheta_{1 i}^{+} \Delta \operatorname{INTSR}_{t-1}^{+}+\vartheta_{2 i}^{-} \Delta \operatorname{INTSR}_{t-1}^{-}\right)+ \\
& +\sum_{i=0}^{q-1}\left(\Psi_{1 i}^{+} \Delta M A N U F_{t-1}^{+}+\Psi_{2 i}^{-} \Delta M A N U F_{t-1}^{-}\right)+\pi E C T_{t-1}+e_{t}
\end{aligned}
$$

Where $\pi$ represents the coefficient of the speed of adjustment to long-run equilibrium, and ECT is the error correction term.

\section{Empirical data and analysis}

\subsection{Data series selection and index construction}

To measure the net foreign financial inflows into South Africa, monthly net foreign purchases of shares (NFPS) and bonds (NFPB) series from the South African Reserve Bank (SARB) over the sample period from January 1995 to June 2018 were employed. These series represent the total market value of South African stocks and bonds purchased by foreign investors minus the total market value of stocks and bonds they sold (SARB, 2018). The descriptive statistics of these two series are shown in Table A2 of the Appendix, and Figures 1 and 2 below depict the trend of NFPS and NFPB.

Figure 1: Net foreign purchases of shares (1995:01 - 2018:06)

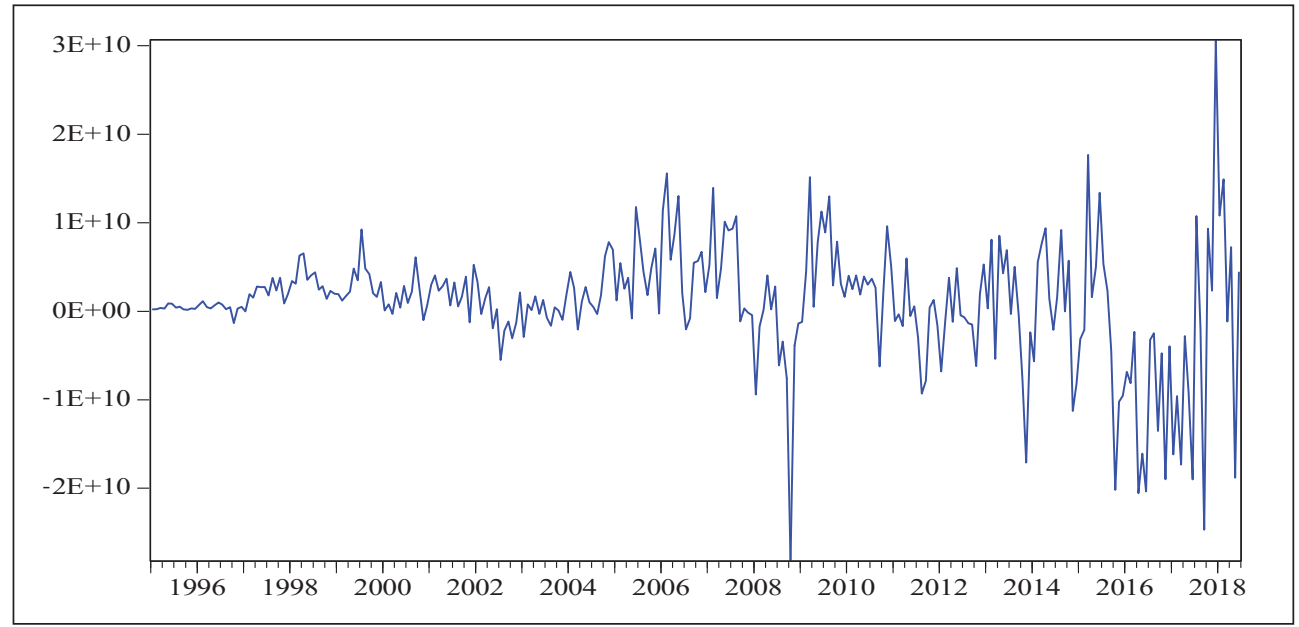

Source: Authors' depiction 
Figure 2: Net foreign purchases of bonds (1995:01 - 2018:06)

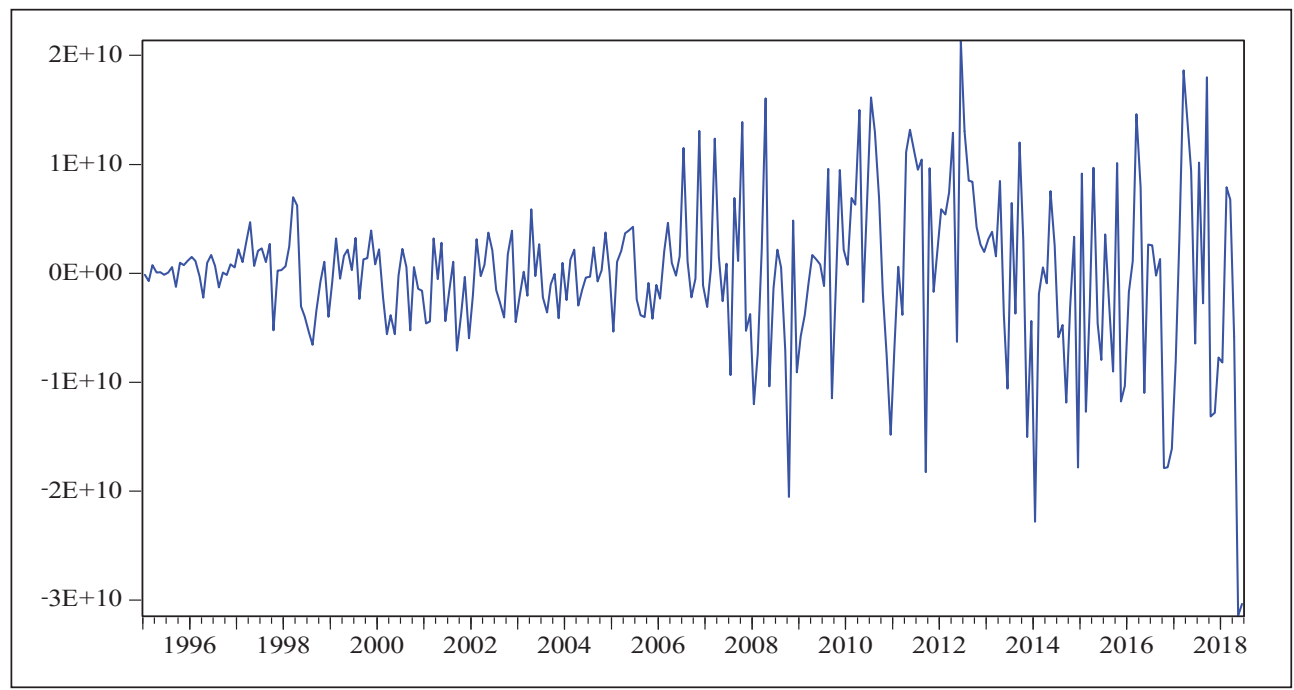

Source: Authors' depiction

For market-wide investor sentiment, no uncontroversial measure exists. Measures that have been used in literature continue to evolve from surveys to lexicons and proxies. Researchers such as Brown and Cliff (2004, 2005), Zwergel and Klein (2006), Schmeling (2007), Lux (2011) Hengelbrock et al. (2011) and Finter et al. (2012) used surveys to measure sentiment. Surveys can capture the psychological dimension of investors and are independent of sophisticated financial theories. However, Baker and Wurgler (2007) argue that surveys are subject to confounding influences due to the potential gap between how people respond to a survey and how they behave. Surveys are also not representative of the overall sentiment as their sample sizes are often limited (Bormann, 2013). Their results also do not always correspond to investor sentiment at a given point in time but to a mix of recent and old opinions (Beer and Zouaoui, 2011). Surveys are also only available in more developed markets such as the U.S and not available in South Africa.

Citing the limitations of surveys, some studies employed lexicons to categorise words and glean the tone of articles to draw inferences about investors' prevailing sentiment (Tetlock, 2007; García, 2013; Smales, 2014). However, this process requires sophisticated automated programs such as the General Inquirer or the Thomson Reuters News Analytics. Also, lexicons require that there be news agencies or financial journals with a strong following, such as the Wall Street Journal, from which the tone of the articles can be gleaned. A third approach entails the use of proxies. These include closed-end equity fund discounts, odd lot sales and net mutual fund redemptions (Neal and Wheatley, 1998), trading activity and 
derivative variables (Brown and Cliff, 2004), share turnover, first-day returns on initial public offers and dividend premiums (Baker and Wurgler, 2006). Other studies by Brown and Cliff (2005) employed the ratio of odd-lot sales to purchases, net mutual fund flows, and the number of IPOs in a month. In the same manner, Qiu and Welch (2006) also used optimism and the consumer confidence indices, Finter et al. (2008) used equity-debt and put-call ratios, and Ben-Raphael et al. (2012) employed aggregate mutual fund flows on domestic and international equity funds, mixed funds and bond funds. Additionally, more recent studies have started exploring variables from social networks as proxies for measuring investor sentiment (Zhang et al., 2018; Chen et al., 2019; Li et al., 2019).

Sentiment proxies have become popular because they are based on simple market data. Also, proxies are observable in real-time and reflect both the power and the strength of bullishness or bearishness of market participants. However, they rely on controversial theoretical explanations to link them to sentiment, lack exclusivity in measuring sentiment and contain idiosyncratic noise. The sheer number of proxies used in literature also reflects the fact that there is no clear guide in selecting and using them. The remedy to some of these drawbacks involves combining proxies into composite indices. Although such indices lack the directness of surveys, they can capture sentiment from different angles as they take into account multiple sources of information and filter out the idiosyncratic noise to better reflect changes in sentiment than individual measures used (Beer and Zouaoui, 2013). Accordingly, authors such as Brown and Cliff (2004), Bandopadhyaya and Jones (2006), Baker and Wurgler (2006), Liao, Huang and $\mathrm{Wu}$ (2011), Beer and Zouaoui (2011) and Chen et al. (2014) employed proxies to construct composite indices.

In South Africa, the practice of using proxies is common as the Momentum Investment Group has a Momentum Investor Confidence Index (MICI) constructed using different equally weighted proxies. Accordingly, a set of proxies was employed to construct a monthly composite investor sentiment index using data obtained from the SARB over the sample period from January 1995 to June 2018. The first proxy is share turnover (Turn), determined as the ratio of share volume traded to the average number of shares listed on the South African stock exchange market. The choice of this proxy followed Baker and Stein (2004) who found that in a market where there are short-sales constraints, the incidence of irrational noise traders is generally high as they cannot be easily driven out of the market through arbitrage activities by their rational counterparts. This group of investors only participates in the market when they are overly optimistic, which often results in an overvaluation of financial securities. The second proxy is the equity issue ratio (Equity), determined as the share of equity issues in total equity and debt issues in South Africa. The choice of this variable followed Baker and Wurgler (2006; 2007) who found that high values of the equity share issues predict low market 
returns. This is because when companies want to expand, they usually issue equity when sentiment is high and equity is overvalued to issue less equity for the amount required. Overvaluation is common in high sentiment periods where the incidence of sentiment-driven traders that underestimate risks and overestimate returns is at its peak (Baker and Wurgler, 2006).

The third proxy, the Advance/Decline ratio (AdvDec), measures the number of shares advancing versus the number of shares declining, adjusted for their volumes. Positive market breadth entails bullish sentiment whereas negative market breadth entails bearish sentiment (Brown and Cliff, 2004). The bid-ask spreads between the domestic currency of Rand and the U.S. Dollar (BidAskD), Euro (BidAskE) and Pound (BidAskP) made up the next proxies. Bid-ask spreads are mostly influenced by the underlying demand for domestic securities. The expectation of poor economic performance breeds negative sentiment, resulting in declining capital inflows. This leads to the widening of the bid-ask spread as foreign investors shun Rand-denominated securities. The opposite applies to positive expectations (Hengelbrock et al., 2011). For the last proxy, the term structure of interest rates (TSIR), the examination of its shape which captures differences in the yields of bonds with varying maturities can help gauge the relative attractiveness of investing in long-term bonds against the opportunity cost of holding near-cash investments (Sayim and Rahman, 2013). A positive spread indicates low short-term rates and high short-term liquidity, which investors can use to finance long-term returns, while a negative spread indicates low short-term liquidity and poor economic performance (Brunnermeier and Pedersen, 2008).

The proxies were first orthogonalized against macroeconomic variables to ensure that the remaining component is purely behavioural and not incremental to macroeconomic risk factors. The principal component analysis technique was then applied. Brown and Cliff (2004) argue that equal weights fail to eradicate collinearity among the variables. However, the principal component analysis uses orthogonal transformation to translate a set of correlated series into an array of linearly uncorrelated ones. Starting with a linearly independent set of vectors $(\mathrm{v} 1, \ldots, \mathrm{vk})$ in an inner product space, orthogonalisation results in a set of orthogonal vectors $\{\mathrm{u} 1, \ldots, \mathrm{uk}\}$ that generate the same subspace as the vectors $(\mathrm{v} 1, \ldots, \mathrm{vk})$. Every vector in the new set is orthogonal to every other vector, which eradicates collinearity (Haiming and Wenlin, 2005). Stambaugh et al. (2012) note that using principal component analysis filters out the idiosyncratic noise in proxies and captures the common component. The principal components were obtained by computing the eigenvalue decomposition of the observed variance matrix. The first principal component is the unit length linear combination of the original variables with maximum variance. Successive principal components maximize variance among unit-length linear combinations that are orthogonal to the preceding components (Hu and Tsay, 2014). 
According to Baker and Wurgler (2006), some sentiment proxies may need to be lagged, as they take longer to reveal sentiment than others. If a proxy takes longer to reveal sentiment, then lagging it allows sentiment effects to be revealed within the following month. Accordingly, an index with the first principal components of the current values as well as the one-period lagged values was constructed as:

$$
\begin{aligned}
\text { Sentiment }_{t}= & \theta_{1} \text { Turn }_{i, t-1}+\theta_{2} \text { Turn }_{i, t}+\theta_{3} \text { Equity }_{i, t-1}+\theta_{4} \text { Equity }_{i, t}+ \\
& +\theta_{5} \text { AdvDec }_{i, t-1}+\theta_{6} \text { AdvDec }_{i, t}+\theta_{7} \text { BidAskD }_{i, t-1}+ \\
& +\theta_{8} \text { BidAskD }_{i, t}+\theta_{9} \text { BidAskP }_{i, t-1}+\theta_{10} \text { BidAskP }_{i, t}+ \\
& +\theta_{11} \text { BidAskE }_{i, t-1}+\theta_{12} \text { BidAskE }_{i, t}+\theta_{13} \text { TSIR }_{i, t-1}+ \\
& +\theta_{14} \text { TSIR }_{i, t}
\end{aligned}
$$

Where: $\theta_{\mathrm{i}}$ represents the factor loadings on the first principal components of the proxies - lagged and contemporaneous. Subsequently, the correlation between the first stage index and the current and lagged values of each of the proxies were examined to determine whether the lagged or the current values of each of the proxies better reveal sentiment effects. This approach follows Baker and Wurgler (2006). The sentiment index, InvSent, was then defined as the first principal component of the correlation matrix of the factors - each corresponding proxy's current or lagged value, whichever has a greater correlation with the first-stage index as:

$$
\begin{aligned}
\text { InvSent }_{t}= & \theta_{1} \text { Turn }_{i, t / t-1}+\theta_{2} \text { Equity }_{i, t / t-1}+\theta_{3} \text { AdvDec }_{i, t / t-1}+\theta_{3} \text { BidAskD }_{i, t / t-1}+ \\
& +\theta_{3} \text { BidAskP }_{i, t / t-1}+\theta_{3} \text { BidAskE }_{i, t / t-1}+\theta_{3} \text { TSIR }_{i, t / t-1}
\end{aligned}
$$

While Equation 6 allows for the determination of the proxies' timing in revealing sentiment, it is not the final index. The final index is yielded by Equation 7 above. The results from the principal component analysis are in Table A1 of the Appendix.

\subsection{Model estimation and empirical results}

\subsubsection{The composite sentiment index}

The constructed composite sentiment index has certain desirable qualities. Firstly, all seven proxies enter the final equation with the expected sign. Secondly, all of the proxies enter the equation with the expected timing in reflecting sentiment. Thirdly, the creation of the index eradicates some extreme values in some of the proxies such as the Trading volume, for instance. This is important because, according to Baker and Wurgler (2006), for the proxies to work as predictors of a single phenomenon, their levels of extremity must be matched by extremity in the returns. This would not have been the case if the component analysis procedure had not been used. Thus, our sentiment index met all desirable qualities. 
Figure 3: Composite investor sentiment index, InvSent (1995:01 - 2018:06)

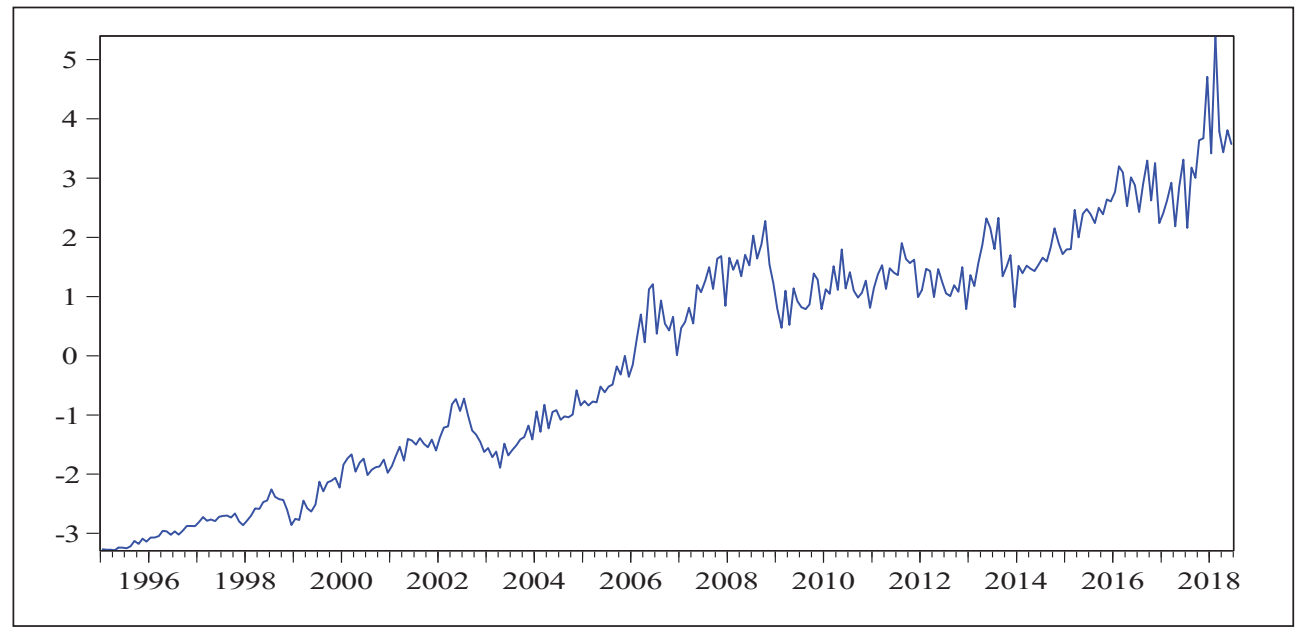

Source: Authors' depiction

\subsubsection{Unit root and stationarity tests}

Following the construction of the sentiment index, the determination of the order of integration of all the variables employed in this study - the net purchases of shares and bonds, the sentiment index and the control variables - followed. The ADF and the PP test the null hypothesis of unit roots while the KPSS tests the null hypothesis of stationarity. From the three tests conducted - ADF, KPSS and PP (with trend and intercept) - the results indicated that the variables were either I(0) or I(1). There were no I(2) variables. Therefore, the models could be estimated as they both obviate the need to classify variables into $\mathrm{I}(1)$ or $\mathrm{I}(0)$ and do not produce spurious results if the variables are not I(2) (Akinlo, 2006).

Table 1: Unit roots and stationarity tests

\begin{tabular}{|l|c|c|c|c|c|c|c|}
\cline { 2 - 8 } \multicolumn{1}{c|}{} & \multicolumn{2}{c|}{ ADF test statistics } & \multicolumn{2}{c|}{ PP test statistics } & \multicolumn{2}{c|}{ KPSS test statistics } & \multirow{2}{*}{$\begin{array}{c}\text { Order of } \\
\text { integration }\end{array}$} \\
\cline { 2 - 8 } \multicolumn{1}{c|}{} & Level & $1^{\text {st }}$ Diff. & Level & $1^{\text {st }}$ Diff. & Level & $1^{\text {st }}$ Diff. & iffer \\
\hline NFPS & $-6.98^{* * *}$ & ------ & $-11.9^{* * *}$ & ----- & $0.14^{*}$ & $0.11^{*}$ & $\mathrm{I}(0)$ \\
\hline NFPB & $-12.51^{* * *}$ & ------ & $-12.58^{* * *}$ & ------ & $0.15^{* *}$ & $0.50^{* * *}$ & $\mathrm{I}(0)$ \\
\hline INVSNT & -2.82 & $-24.57^{* * *}$ & $-4.02^{* * *}$ & ----- & 0.08 & ----- & $\mathrm{I}(0)$ \\
\hline MANUF & -2.50 & $-23.57^{* * *}$ & $-3.25^{*}$ & ----- & $0.26^{* * *}$ & 0.02 & $\mathrm{I}(1)$ \\
\hline ALSIR & $-12.84^{* * *}$ & ------ & $-12.50^{* * *}$ & ----- & 0.04 & ----- & $\mathrm{I}(0)$ \\
\hline RDEX & -2.23 & $-11.94^{* * *}$ & -1.97 & $-11.80^{* * *}$ & $0.19^{* *}$ & 0.06 & $\mathrm{I}(1)$ \\
\hline INTSR & $-3.42^{*}$ & ------ & $-3.34^{*}$ & ----- & $0.16^{* *}$ & 0.06 & $\mathrm{I}(0)$ \\
\hline
\end{tabular}

Note: $\mathrm{I}(0)$ and $\mathrm{I}(1)$ denote stationarity in levels and first differences, respectively. *, ** and *** denote significance at $10 \%, 5 \%$ and $1 \%$, respectively.

Source: Authors' estimations 
Hilary Tinotenda Muguto et al. •Investor sentiment and foreign financial flows...

\subsubsection{Analysis of the long-run relationships}

Before the analysis of the results, the most apposite models for both financial flow series had to be chosen using the SBIC. The table below depicts the ARDL and NARDL model selections and information criteria. Based on the SBIC, the most appropriate models were ARDL $(2,3,0,1,1,0)$ for net foreign purchases of shares and NARDL $(1,1,0,0,0,0,0,1,0,0,0)$ for the net foreign purchases of bonds. The values in the brackets reflect the number of lags on each explanatory variable in the models. The results show that the net foreign purchases of shares are explained by a linear relationship, while the net foreign purchases of bonds are explained by a non-linear relationship. This suggests that the effect of positive sentiment on net foreign purchases of bonds is different from that of negative sentiment but this is not the case with net foreign purchases of shares. Subsequently, model diagnostic tests were conducted. The Breusch-Godfrey serial correlation tests showed that there is no serial correlation and the CUSUM and CUSUM of squares tests also showed that both models are stable. From the F-Bounds test in Table 2, there is an indication that there is a cointegrating relationship among the variables at the 5 percent significance level for both series. The F-statistics of 5.6781 (NFPFS) and 20.2942 (NFPFB) are all greater than the upper bound Pesaran critical value of 3.38. This means that there is a long-run relationship between the variables.

Table 2: ARDL and NARDL model selection and Bound test results

\begin{tabular}{|c|l|c|c|c|c|}
\cline { 3 - 6 } \multicolumn{1}{c|}{ Model } & \multirow{2}{*}{ SBIC } & \multirow{2}{*}{ F-statistic } & \multicolumn{2}{c|}{ Critical values } \\
\cline { 5 - 7 } \multicolumn{1}{c|}{} & \multicolumn{2}{|c|}{$\begin{array}{c}\text { Lower } \\
\text { bound }\end{array}$} & $\begin{array}{c}\text { Upper } \\
\text { bound }\end{array}$ \\
\hline \multirow{2}{*}{ NFPS } & ARDL $(2,3,0,1,1,0)$ & 47.9247 & 5.6781 & 3.12 & 4.25 \\
\cline { 2 - 6 } & NARDL $(2,1,0,0,0,0,0,0,0,0,0)$ & 47.97946 & 6.0748 & 2.33 & 3.46 \\
\hline \multirow{2}{*}{ NFPB } & ARDL $(7,8,0,0,1,0)$ & 48.3473 & 7.6251 & 3.12 & 4.25 \\
\cline { 2 - 6 } & NARDL $(1,1,0,0,0,0,0,1,0,0,0)$ & 48.2687 & 20.2942 & 2.33 & 3.46 \\
\hline
\end{tabular}

Note: Pesaran et al. (2001) critical values are based on Case V: Unrestricted intercept and unrestricted trend

Source: Authors' estimations

The long-run (level) equations yielded by the ARDL for net foreign purchases of shares and NARDL for net foreign purchases of bonds, respectively, as specified as:

$$
\begin{aligned}
\text { NFPS }= & -5604664044.19 \text { INVSENT }+511551476.98 \text { MANUF }+ \\
& +27334385266.38 \text { ALSIR }+1051976762.48 \text { RDEX }+ \\
& +202168858.63 \text { INTSR }
\end{aligned}
$$




$$
\begin{aligned}
\text { NFPB }= & -6590955507.28 \text { INVSENT }_{P O S}-4753427147.06 \text { INVSENT }_{N E G}+ \\
& +793366450.64 \text { MANUF }_{P O S}+188570078.57 \text { MANUF }_{N E G}- \\
& -7897792048.08 \text { ALSIR }_{\mathrm{POS}}-3605536181.30 \text { ALSIR }_{N E G}+ \\
& +3128801736.95 * \text { RDEX }_{P O S}+776465478.71 \text { RDEX }_{N E G}- \\
& -142954799.22 \text { INTSR }_{P O S}-703915744.38 \text { INTSR_NEG }^{-}
\end{aligned}
$$

The long-run equations show that there is an inverse relationship between investor sentiment and the net foreign purchase of shares. This means that as sentiment increases, investors sell more shares than they buy. On the other hand, all the other control variables have a positive relationship with net foreign purchase of shares. For bond purchases, the relationship is inverse with both positive and negative sentiment. This means that if sentiment increases, net foreign purchases of bonds will decrease and when sentiment decreases, net foreign purchases of bonds will increase. The effect is, however, greater with positive sentiment than negative sentiment, highlighting the asymmetric effect of sentiment on bond purchases in the absence thereof on share purchases. Similar patterns of having consistent relationships for either negative or positive coefficients can be observed in the control variables. However, the impact is greater for positive changes in all the variables, except interest rates.

\subsubsection{Analysis of short-run relationships}

Pursuant to establishing that there is indeed a long-run relationship between sentiment and net foreign capital flows, error correction models were estimated to examine the short-run dynamics and the speed of adjustment to the long-run equilibrium. The results of the estimations are reported in Table 3, parts A and B. From Table 3, it is importantly evident that the error correction term, ECT, is both negative and statistically significant for both estimations. The error term's significance means that there is a correction for disequilibrium in each period as the series moves back into the long-run cointegrating relationship. The term is, however, larger for the bonds' equation (-0.8856) than it is for the shares' equation $(-0.4489)$. This suggests that there is quicker correction back to equilibrium in the case of bonds of approximately $1.13(1 / 0.8856)$ months relative to the speed of adjustment of approximately $2.23(1 / 0.4489)$ in shares. The slower correction for shares relative to bonds could be because sentiment-driven traders focus mostly on equity, which can produce significantly high returns in bullish periods relative to the usually fixed-income bonds. Therefore, owing to the more significant impact that sentiment has on equity, a correction back into equilibrium may take longer. It is also possible that other macroeconomic factors have a stronger impact on the equity-sentiment relationship than they do on the bonds-sentiment relationship. The factors may have some confounding influence on the speed of adjustment back into 
Hilary Tinotenda Muguto et al. •Investor sentiment and foreign financial flows...

equilibrium. For example, the bond-interest rate relationship shows that bond markets generally will respond quicker to changes in interest rates than stock markets.

Overall, the ECM results in Table 3 show that sentiment has a short-run effect on net foreign purchases of both bonds and shares, but the effect varies across the lags. Part A of Table 3 shows that the net foreign purchases of bonds are affected by positive changes in sentiment in the short-run with positive changes in current sentiment having a negative effect that becomes positive at lag one. Additionally, the net foreign purchases of bonds are positively affected by their previous changes at lag 2 and 3 but not at lag 1. In Part B of Table 3, the net foreign purchases of shares respond negatively to short-run changes in sentiment up to lag 1 and the response becomes positive at lag 2. The control variables also have short-run effects on both net foreign purchases of bonds and shares, but the effects seem to be negative on net foreign purchases of bonds net as compared to net foreign purchases of shares.

Table 3: Error correction model coefficients for NFPS and NFPB

\begin{tabular}{|c|c|c|c|c|c|}
\hline \multicolumn{3}{|c|}{ Part A: NFPFB ECM Results } & \multicolumn{3}{|c|}{ Part B: NFPFS ECM Results } \\
\hline Variable & Coefficient & Prob. & Variable & Coefficient & Prob. \\
\hline $\mathrm{C}$ & $2.01 \mathrm{E}+09$ & 0.0000 & $\mathrm{C}$ & $-3.21 \mathrm{E}+10$ & 0.0000 \\
\hline @TREND & $-4.30 \mathrm{E}+08$ & 0.0000 & @TREND & 47503395 & 0.0000 \\
\hline $\mathrm{D}(\operatorname{NFPB}(-1))$ & 0.069820 & 0.4158 & D(NFPS $(-1))$ & -0.270966 & 0.0000 \\
\hline $\mathrm{D}(\mathrm{NFPB}(-2))$ & 0.193291 & 0.0096 & D(INVSENT) & $-7.78 \mathrm{E}+09$ & 0.0000 \\
\hline $\mathrm{D}(\operatorname{NFPB}(-3))$ & 0.194934 & 0.0008 & D(INVSENT(-1)) & $-1.52 \mathrm{E}+09$ & 0.0000 \\
\hline D(INVSENT_POS) & $-8.24 \mathrm{E}+09$ & 0.0000 & D(INVSENT(-2)) & $2.34 \mathrm{E}+09$ & 0.0000 \\
\hline D(INVSENT_POS(-1)) & $6.32 \mathrm{E}+09$ & 0.0000 & D(ALSIR) & 35125148 & 0.0000 \\
\hline D(MANUF_NEG) & $-1.66 \mathrm{E}+08$ & 0.0000 & $\mathrm{D}(\mathrm{RDEX})$ & $3.05 \mathrm{E}+09$ & 0.0000 \\
\hline D(MANUF_NEG(-1)) & $2.61 \mathrm{E}+08$ & 0.0000 & ECT & -0.448899 & 0.0000 \\
\hline D(MANUF_NEG(-2)) & $1.61 \mathrm{E}+09$ & 0.0000 & & & \\
\hline D(MANUF_NEG(-3)) & $7.19 \mathrm{E}+08$ & 0.0000 & & & \\
\hline D(ALSIR_POS) & $1.45 \mathrm{E}+10$ & 0.0000 & & & \\
\hline D(ALSIR_POS(-1)) & $-3.32 \mathrm{E}+10$ & 0.0000 & & & \\
\hline D(ALSIR_POS(-2)) & $-2.05 E+10$ & 0.0000 & & & \\
\hline D(ALSIR_NEG) & $-3.27 \mathrm{E}+10$ & 0.0000 & & & \\
\hline D(ALSIR_NEG(-1)) & $-1.10 \mathrm{E}+10$ & 0.0000 & & & \\
\hline D(ALSIR_NEG(-2)) & $-1.30 \mathrm{E}+10$ & 0.0000 & & & \\
\hline D(ALSIR_NEG(-3)) & $-5.20 \mathrm{E}+10$ & 0.0000 & & & \\
\hline D(RDEX_POS) & $-4.06 \mathrm{E}+09$ & 0.0000 & & & \\
\hline ECT & -0.885994 & 0.0000 & & & \\
\hline
\end{tabular}

Source: Authors' estimations 


\section{Results and discussion}

The long-run inverse relationship between investor sentiment and the purchase of both shares and bonds suggests that as the prevailing sentiment towards South African assets increases, the purchase of both shares and bonds declines. This inverse relationship could be a result of noise trader risk, especially given that the South African market is an emerging market (Morck et al., 2000). As sentiment increases, smart money investors and institutional investors may move their money out of South Africa in anticipation of an impending slump in the market, thus causing net outflows. It is also possible that the increases in sentiment bring about increases in stock and bond market volatility as well as the possibility of market crashes and liquidity dry-up, all of which work in concert in inducing or engendering flight for quality from the South African market (Baker and Wurgler, 2007). This finding is consistent with Hassan et al. (2016) who found a significant relationship between sentiment and foreign financial flows in Malaysia. Their findings highlighted the need for the Malaysian government to improve the perception and outlook of the country rather than a blinkered focus on macroeconomic conditions. This may be the same case for South Africa, where the country needs to improve its outlook to boost investor sentiment.

Benhima and Cordonier (2018) also found that surges in optimism are important drivers of gross capital flows, explaining up to 50 percent of the forecast error variance decomposition of capital flows for a panel of 18 OECD economies. Sentiment shocks triggered both positive inflows and outflows, which suggests that the increase in cross-border capital positions was not related to better macroeconomic fundamentals but rather driven by surges in optimism unrelated to future productivity. Of note, however, the contemporaneous relationship between sentiment and foreign financial flows can be either positive or negative. According to French and Li (2015), if foreign equity flows are primarily driven by the rational aggregate demand of equity, investor sentiment and foreign equity flows will be negatively correlated. However, if foreign equity flows reflect the irrational aggregate demand of equity, investor sentiment and foreign equity flows will be positively correlated. Based on the results from the long run estimations, the negative coefficients imply a greater impact from the rational aggregate demand of South African financial assets from foreign investors relative to the irrational demand.

In the review of the literature above, it was mentioned that high sentiment periods might attract foreign inflows due to robust economic growth and remarkable contemporaneous returns, increased liquidity and the availability of arbitrage opportunities (Baker and Stein, 2004; Tetlock, 2007). However, the patterns in the South African case seem to suggest the contrary. The negative contemporaneous relationship shows that issues such as noise trader risk and limits to arbitrage (De Long et al., 1990), increased speculation and volatility on markets and the possibility of market crashes (Lee et al., 2002) have a stronger impact. 
The positive relationship between manufacturing production and foreign financial flows is conceivable because an increase in manufacturing production is associated with a growing economy. Investors are likely to purchase more stocks and bonds as higher returns are expected when the economy is performing well. Companies usually borrow to expand as debt is usually cheaper than equity (Gaud et al., 2007), which increases returns of bonds, and they make more profits from expanded operations, which increase returns on equity. With the Rand/Dollar exchange rate, the positive relationship with both series suggests that as the Rand appreciates, investments in South Africa become attractive as a currency appreciation is often associated with a strengthening economy (Muzindutsi and Niyimbanira, 2012). This relationship due to portfolio rebalancing. This is because foreign investors are constricted or motivated to invest by the exchange rate and they rebalance their portfolios when there has been a movement in the exchange rate to maintain or lower risk levels per unit of returns (Hau and Rey, 2006).

Unlike the consistent impacts exhibited by sentiment, manufacturing production and exchange rates on share and bond purchases, interest rates and All share returns affect the two series differently - the impact is positive with the purchase of shares and negative with the purchase of bonds. This suggests that as the South African interest rates increase, investors will purchase more shares as stock markets are expected to grow with higher interest rates. In a rising interest rate environment, stocks can thus be an attractive substitute to bonds; therefore, bondholders tend to divest from bonds and invest in stocks. This is highlighted in the relationship between these series and the returns on the All Share Index. Stock markets and bond markets are substitute investment platforms so if the stock market is performing well, investors will channel their investments to stock markets from bond markets. Although there has been some evidence of decoupling between stocks and bonds recently (Anderssson et al., 2008), the traditional negative relationship between the two types of securities seems to hold in South Africa.

\section{Conclusions}

This paper proposed that a significant component of foreign financial flows is driven by the investor sentiment prevailing in each period. To test this hypothesis, the ARDL model was applied, and the results show that there is a significant longrun association between sentiment and these foreign financial flows, corroborating the claim made at the commencement of this study that investor sentiment, in addition to other fundamental factors, has an impact on foreign financial flows. While there are studies that have examined the drivers of portfolio flows, this study is the first one in South Africa to propose investor sentiment as a driver of these flows and look at disaggregated equity and bond flows instead of the aggregated flows. 
This study is especially important because, although there has been a significant surge in capital flows to emerging markets, there is ample evidence of the overheating of economies and increased vulnerability to swings in capital flows, all of which heightens the need to know what drives these flows. While good economic performance is significant in attracting foreign portfolio flows, this study argued that that is not enough for South Africa. Instead, in addition to economic stability, South Africa must improve its perception outlook and create a conducive atmosphere for investment. This is especially important for South Africa due to its status as an emerging market, a type of market that is already viewed as risky relative to more developed markets and, thus, highly susceptible to the risk of flight for quality.

As argued in literature, portfolio flows have great volatility because they are not that costly to reverse. Therefore, if policymakers are to reduce this volatility and flight for quality, the importance of maintaining a positive perception cannot be overstated. Also, the investor composition of the financial markets poses a challenge for South Africa. One of the significant structural constraints in the South African economy is the low level of savings and domestic ownership of companies. This means that South Africa depends significantly on foreign capital to fill this gap between the low savings and the productive investment needed to support enough economic growth. A possible extension of this paper involves determining whether there are differences in the relationship between the two net foreign purchases in high and low sentiment periods.

\section{References}

Adeola, O., Aziakpono, M. (2017) "The Relative Contribution of Alternative Capital Flows to South Africa: An Empirical Investigation", Journal of Economic \& Financial Sciences, Vol. 10, No. 1, pp. 69-82.

Agarwal, R. N. (1997) "Foreign Portfolio Investment in Some Developing Countries: A Study of Determinants and Macroeconomic Impact", Indian Economic Review, Vol. 1, No. 1, pp. 217-229.

Akinlo, A. E. (2006) "The Stability of Money Demand in Nigeria: An Autoregressive Distributed Lag Approach", Journal of Policy Modeling, Vol. 28, No. 4, pp. 445-452.

Albuquerque, R. (2003) "The Composition of International Capital Flows: Risk Sharing Through Foreign Direct Investment", Journal of International Economics, Vol. 61, No. 2, pp. 353-383.

Andersson, M., Krylova, E., Vähämaa, S. (2008) "Why Does the Correlation Between Stock and Bond Returns Vary Over Time"?, Applied Financial Economics, Vol. 18, No. 2, pp. 139-151.

Baker, M., Stein, J. C. (2004) "Market Liquidity as A Sentiment Indicator”, Journal of Financial Markets, Vol. 7, No. 3, pp. 271-299. 
Baker, M., Wurgler, J. (2006) "Investor Sentiment and The Cross-Section of Stock Returns", Journal of Finance, Vol. 61, No. 4, pp. 1645-1680.

Baker, M., Wurgler, J. (2007) "Investor Sentiment in The Stock Market", Journal of Economic Perspectives, Vol. 21, No. 2, pp. 129-152.

Baker, M., Wurgler, J., Yuan, Y. (2012) "Global, Local, and Contagious Investor Sentiment”, Journal of Financial Economics, Vol. 104, No. 2, pp. 272-287.

Bandopadhyaya, A., Jones, A. L. (2006) "Measuring Investor Sentiment in Equity Markets", Journal of Asset Management, Vol. 7, No. 3, pp. 208-215.

Beer, F., Zouaoui, M. (2012) "Measuring Stock Market Investor Sentiment", Journal of Applied Business Research, Vol. 29, No. 1, pp. 1-51.

Beer, F., Zouaoui, M. (2013) "Measuring Stock Market Investor Sentiment", Journal of Applied Business Research, Vol. 29, No. 1, pp. 51-68.

Benhima, K. Cordonier, R. (2018)“News, Sentiment and Capital Flows", Working Paper, 1-40.

Black, F. (1986) "Noise”, Journal of Finance, Vol. 41, No. 3, pp. 528-543.

Bormann, S. K. (2013) "Sentiment Indices on Financial Markets: What Do They Measure"?, Economics Discussion Papers, pp. 1-33.

Brennan, M. J., Cao, H. H. (1997) "International Portfolio Investment Flows", Journal of Finance, Vol. 52, No. 5, pp. 1851-1880.

Brown, G. W., Cliff, M. T. (2004) "Investor Sentiment and The Near-Term Stock Market", Journal of Empirical Finance, Vol. 11, No. 1, pp. 1-27.

Brunnermeier, M. K., Pedersen, L. H. (2008) "Market Liquidity and Funding Liquidity", Review of Financial Studies, Vol. 22, No. 6, pp. 2201-2238.

Burghardt, M., Czink, M., Riordan, R. (2008) "Retail Investor Sentiment and The Stock Market", Working Paper, Social Science Research Network, pp. 1-63.

Chen, R., Yu, J., Jin, C., Bao, W. (2019) "Internet Finance Investor Sentiment and Return Comovement”, Pacific-Basin Finance Journal, Elsevier, Vol. 56, No. 1, pp. 151-161.

Clark, G. L., Wójcik, D. (2007) The Geography of Finance: Corporate Governance in The Global Marketplace, United Kingdom: Oxford University Press.

Coeurdacier, N., Guibaud, S. (2011) "International Portfolio Diversification Is Better Than You Think", Journal of International Money \& Finance, Vol. 30, No. 2, pp. 289-308.

De Beer, B. (2015) "South Africa's Experience with Capital Flows Since the Financial Crisis: From Measurement to Analysis". In Proceedings of the 60th ISI Conference, 25-26 March, Rio De Janeiro, Brazil, pp. 1-40.

De Long, J. B., Shleifer, A., Summers L. H., Waldmann R. J. (1990) "Noise Trader Risk in Financial Markets", Journal of Political Economy, Vol. 98, No. 4, pp. 703-738. 
De Santis, R. A., Lührmann, M. (2009) "On the Determinants of Net International Portfolio Flows: A Global Perspective", Journal of International Money \& Finance, Vol. 28, No. 5, pp. 880-901.

Dornbusch, R., Park, Y. C., Claessens, S. (2000) "Contagion: How It Spreads and How It Can Be Stopped”, World Bank Research Observer, Vol. 15., No. 2, pp. 177-197.

Eichengreen, B., Hausmann, R. (1999) "Exchange Rates and Financial Fragility", Working Paper, National Bureau of Economic Research, pp. 1-40.

Eichengreen, B., Mussa, M., Dell'Ariccia, G., Detragiache, E., Maria, G., MilesiFerretti, A. T. (1999) "Liberalizing Capital Movements: Some Analytical Issues”, International Monetary Fund, Washington, DC, United States of America.

Errunza, V. (2001) "Foreign Portfolio Equity Investments, Financial Liberalization, and Economic Development", Review of International Economics, Vol. 9, No. 4, pp. 703-726.

Evans, M. D., Hnatkovska, V. V. (2014) "International Capital Flows, Returns and World Financial Integration", Journal of International Economics, Vol. 92, No. 1, pp. 14-33.

Fedderke, J. W., Romm, A. T. (2006) "Growth Impact and Determinants of Foreign Direct Investment into South Africa, 1956-2003”, Economic Modelling, Vol. 23, No. 5, pp. 738-760.

Finter, P., Niessen-Ruenzi, A., Ruenzi, S. (2012) “The Impact of Investor Sentiment on The German Stock Market", Zeitschrift Für Betriebswirtschaft, Vol. 82, No. 2, pp. 133-163.

Fisher, K. L., Statman, M. (2003) "Consumer Confidence and Stock Returns", Journal of Portfolio Management, Vol. 30, No. 1, pp. 115-127.

French, J. J., Li, W. X. (2015) "Investor Sentiment, Foreign Equity Flows, and Equity Returns in Thailand Stock Markets", Working Paper, National Bureau Of Economic Research, pp. 1-13.

French, J. J., Li, W. X. (2017) "Sentiment, Foreign Equity Flows, and Returns: Evidence from Thailand's Stock Markets", Research in International Business \& Finance, Vol. 42, No. 1, pp. 816-831.

García, D. (2013) "Sentiment During Recessions”, Journal of Finance, Vol. 68, No. 3, pp. 1267-1300.

Gaud, P., Hoesli, M., Bender, A. (2007) "Debt-Equity Choice in Europe", International Review of Financial Analysis, Vol. 16, No. 3, pp. 201-222.

Haiming, L., Wenlin, Z. (2005) "The Relationship Between Principal Component Analysis and Factor Analysis and SPSS Software", Statistical Research, Vol. 3, No. 1, pp. 65-69.

Hassan, M. K., Rashid, M., Castro, E. (2016) "Foreign Direct Investment and Investor Sentiment: A Causal Relationship", Global Economy Journal, Vol. 16, No. 4, pp. 697-719. 
Hau, H., Rey, H. (2004) "Can Portfolio Rebalancing Explain the Dynamics of Equity Returns, Equity Flows, and Exchange Rates"?, American Economic Review, Vol. 94, No. 2, pp. 126-133.

Helmut, R. (2000) Pensions, Savings and Capital Flows from Ageing to Emerging Markets: From Ageing to Emerging Markets, Paris, France: OECD Publishing.

Hengelbrock, J., Theissen, E., Westheide, C. (2011) "Market Response to Investor Sentiment", Working Paper, Centre for Financial Research, pp. 1-34.

Hu, Y. P., Tsay, R. S. (2014) "Principal Volatility Component Analysis", Journal of Business \& Economic Statistics, Vol. 32, No. 2, pp. 153-164.

Hui, E. C. M., Wang, Z. (2014) " Market Sentiment in The Private Housing Market", Habitat International, Vol. 44, No. 1, pp. 375-385.

Igan, M. D. O., Kutan, A. M., Mirzae, A. (2017) "Real Effects of Capital Inflows in Emerging Markets", Working Paper, International Monetary Fund, pp. 1-49.

Kaminsky, G. L., Reinhart, C. M. (2000) "On Crises, Contagion, and Confusion", Journal of International Economics, Vol. 51, No. 1, pp. 145-168.

Kariuki, C. (2015) "The Determinants of Foreign Direct Investment in The African Union", Journal of Economics, Business \& Management, Vol. 3, No. 3, pp. 346-351.

Kregel, J. A. (2004) "External Financing for Development and International Financial Instability", United Nations, Vol. 1, No. 32, pp. 1-34.

Lawrence, E. R., Mccabe, G., Prakash, A. J. (2007) "Answering Financial Anomalies: Sentiment-Based Stock Pricing”, Journal of Behavioural Finance, Vol. 8, No. 3, pp. 161-171.

Li, C., Tan, S. R., Ho, N., Chia, W. M. (2019) "Investor Sentiment, Behavioral Heterogeneity and Stock Market Dynamics", Working Paper, Social Science Research Network, pp. 1-62.

Lux, T. (2011) "Sentiment Dynamics and Stock Returns: The Case of The German Stock Market", Empirical Economics, Vol. 41, No. 3, pp. 663-679.

Muzindutsi, P. F., Niyimbanira, F. (2012). "The exchange rate risk in the Johannesburg stock market: An application of the arbitrage pricing model", Journal of Global Business and Technology, Vol, 8, No. 1, pp. 60-70.

Morck, R., Yeung, B., Yu, W. (2000) "The Information Content of Stock Markets: Why Do Emerging Markets Have Synchronous Stock Price Movements"?, Journal of Financial Economics, Vol. 58, No. 1, pp. 215-260.

Nistor, P. (2015) "FDI Implications on BRICS Economy Growth", Procedia Economics \& Finance, Vol. 32, No. 1, pp. 981-985.

Nyangoro, O. (2013) "Foreign Portfolio Flows and Stock Market Performance in Kenya: Case of Nairobi Securities Exchange", In Proceedings of the CSAE Conference on Economic Development in Africa, 28-29 April, Nairobi, Kenya, $1-45$. 
Ordu-Akkaya, B. M., Soytas, U. (2019) "Does Foreign Portfolio Investment Strengthen Stock-Commodity Markets Connection"?, Resources Policy, Vol. 65, No. 1, pp. 1-13.

Pástor, L., Stambaugh, R. F. (2003) "Liquidity Risk and Expected Stock Returns", Journal of Political Economy, Vol. 111, No. 3, pp. 642-685.

Pesaran, M. H., Shin, Y., Smith, R. J. (2001) "Bounds Testing Approaches to The Analysis of Level Relationships", Journal of Applied Econometrics, Vol. 16, No. 3, pp. 289-326.

Qiu, L., Welch, I. (2006) “Investor Sentiment Measures". Working Paper, National Bureau of Economic Research, pp. 1-29.

Reisen, H., Soto, M. (2001) "Which Types of Capital Inflows Foster DevelopingCountry Growth"?, International Finance, Vol. 4, No. 1, pp. 1-14.

Resilience, U. (2011) "Sustaining MDG Progress in An Age of Economic Uncertainty", Bureau for Development Policy, Vol. 1, No. 25, pp. 1-36.

Sartorius, K., Botha, G. (2008) "Black Economic Empowerment Ownership Initiatives: A Johannesburg Stock Exchange Perspective", Development Southern Africa, Vol. 25, No. 4, pp. 437-453.

Sayim, M., Rahman, H. (2015) "An Examination of US Institutional and Individual Investor Sentiment Effect on The Turkish Stock Market", Global Finance Journal, Vol. 26, No. 1, pp. 1-17.

Schmeling, M. (2007) "Institutional and Individual Sentiment: Smart Money and Noise Trader Risk"?, International Journal of Forecasting, Vol. 23, No. 1, pp. 127-145.

Smales, L. A. (2014) "News Sentiment and The Investor Fear Gauge", Finance Research Letters, Vol. 11, No. 2, pp. 122-130.

Stambaugh, R. F., Yu, J., Yuan, Y. (2012) "The Short of It: Investor Sentiment and Anomalies", Journal of Financial Economics, Vol. 104, No. 2, pp. 288-302.

Strauss, I. (2017) "Understanding South Africa's Current Account Deficit: The Role of Foreign Direct Investment Income", Transnational Corporations, Vol. 23, No. 2, pp. 49-80.

Stulz, R. M. (1999) International Portfolio Flows and Security Markets", Working Paper, National Bureau Of Economic Research, pp. 1-26.

Sunde, T. (2017) "Foreign Direct Investment, Exports and Economic Growth: ADRL and Causality Analysis for South Africa", Research in International Business and Finance, Vol. 41, No. 1, pp. 434-444.

Taylor, M. P., Sarno, L. (1997) "Capital Flows to Developing Countries: Long-and Short-Term Determinants", World Bank Economic Review, Vol. 11, No. 3, pp. 451-470.

Teti, E., Dell'Acqua, A., Etro, L. and Ruilei, J. (2017) "International Portfolio Diversification", International Journal of Accounting \& Finance, Vol. 7, No. 4, pp. 352-382. 
Tetlock, P. C. (2007). "Giving Content to Investor Sentiment: The Role of Media in The Stock Market", Journal of Finance, Vol. 62, No. 3, pp. 1139-1168.

Thomas, L. (2017) "Ownership Of JSE-Listed Companies", Research Report for National Treasury [Internet], Available at: http://www.treasury.gov.za/comm media/press/2017. [Accessed 4 December 2018].

Zhang, G., Wang, J., Guo, H., Zhang, X. (2018) "The Relationship Between Investor Sentiment and Stock Market Volatility: Based on The VAR Model". In Proceedings of the Wuhan International Conference On E-Business, 6 June, China, pp. 173-180.

Zwergel, B., Klein, C. (2006) "On the Predictive Power of Sentiment-Why Institutional Investors Are Worth Their Pay", Working Paper, National Bureau Of Economic Research, pp. 1-32. 


\title{
Raspoloženje investitora i inozemni financijski tokovi na primjeru Južne Afrike
}

\author{
Hilary Tinotenda Muguto ${ }^{1}$, Lorraine Rupande ${ }^{2}$, Paul-Francois Muzindutsi ${ }^{3}$
}

\begin{abstract}
Sažetak
Inozemni financijski tokovi na tržištima u nastajanju postaju sve važniji nakon otvaranja globalnih financijskih tržišta. Ti su financijski tokovi jedna od temeljnih funkcija neke zemlje koji se odnose na buduću produktivnost. Međutim, osnove makroekonomije ne mogu objasniti neke od obrazaca u tim financijskim tokovima, a posebno se to odnosi na tržišta u nastajanju. $U$ ovom se istraživanju testiralo može li raspoloženje investitora biti korišteno kao alternativno objašnjenje inozemnih financijskih tokova u Južnoj Africi. Koristili smo neto kupnju dionica $i$ obveznica u inozemstvu, a pomoću proxy skupa konstruirali složenu mjeru indeksa raspoloženja investitora. Zatim smo primijenili autoregresivni model $s$ distribuiranim vremenskim pomakom - analizu linearnih i nelinearnih vremenskih serija (ARDL; NARDL) - kako bi se utvrdila veza između raspoloženja investitora i inozemnih dugoročnih i kratkoročnih financijskih tokova. Rezultati su pokazali da raspoloženje značajno utječe na inozemne financijske tokove u Južnu Afriku. Stoga se može zaključiti da će zemlja, osim gospodarske uspješnosti i stabilnosti, morati poboljšati i percepciju svoje zemlje da bi mogla privući inozemne financijske tokove. Ovi rezultati su relevantni za Južnu Afriku kao zemlju koja znatno ovisi o stranom kapitalu da bi se premostio sve dublji jaz između štednje i ulaganja potrebnih za potporu potrebnog gospodarskog rasta.
\end{abstract}

Ključne riječi: inozemni financijski tokovi, raspoloženje investitora, ARDL, NARDL, Južna Afrika

JEL klasifikacija: E7, G1, G3, G4, G28

${ }_{1}$ Doktorand, School of Accounting, Economics and Finance, University of KwaZulu-Natal, Južna Afrika. Znanstveni interes: zdrastveni kapital i financije, financijska tržišta, bihevioralne financije, analiza ulaganja i ekonomija razvoja. Tel.: +27(0)312607871. E-mail: mugutoh@ ukzn.ac.za.

2 Doktorand, School of Accounting, Economics and Finance, University of KwaZulu-Natal, Južna Afrika. Znanstveni interes: financijska tržišta, bihevioralne financije $i$ upravljanje financijskim rizikom.Tel: +27(0)312607871.E-mail: rupandel@ukzn.ac.za.

3 Docent, School of Accounting, Economics and Finance, University of KwaZulu-Natal, Južna Afrika. Znanstveni interes: financijska tržišta, bihevioralne financije i upravljanje financijskim rizikom, određivanje cijene imovine, analiza vremenskih serija makroekonomskih varijabli $i$ ekonomija razvoja. 
Hilary Tinotenda Muguto et al. •Investor sentiment and foreign financial flows...

Zb. rad. Ekon. fak. Rij. • 2019 • vol. $37 \cdot$ no. $2 \cdot 473-498$

\section{Appendices}

Table A1: Principal Components Analysis (1995: 01 - 2018: 06)

\begin{tabular}{|c|c|c|c|c|c|c|c|}
\hline \multicolumn{6}{|c|}{ Eigenvalues: $($ Sum $=7$, Average $=1)$} & & \\
\hline & & & & Cumulative & Cumulative & & \\
\hline Number & Value & Difference & Proportion & Value & Proportion & & \\
\hline 1 & 5.676343 & 5.081973 & 0.8109 & 5.676343 & 0.8109 & & \\
\hline 2 & 0.594370 & 0.275819 & 0.0849 & 6.270713 & 0.8958 & & \\
\hline 3 & 0.318551 & 0.088746 & 0.0455 & 6.589264 & 0.9413 & & \\
\hline 4 & 0.229805 & 0.113882 & 0.0328 & 6.819069 & 0.9742 & & \\
\hline 5 & 0.115923 & 0.075263 & 0.0166 & 6.934991 & 0.9907 & & \\
\hline 6 & 0.040660 & 0.016311 & 0.0058 & 6.975651 & 0.9965 & & \\
\hline 7 & 0.024349 & -- & 0.0035 & 7.000000 & 1.0000 & & \\
\hline \multicolumn{8}{|c|}{ Eigenvectors (loadings) } \\
\hline Variable & PC 1 & PC 2 & PC 3 & PC 4 & PC 5 & PC 6 & PC 7 \\
\hline TURN & 0.379352 & -0.089095 & 0.626164 & -0.175338 & -0.626603 & 0.091015 & 0.156249 \\
\hline EQUITY & 0.392860 & -0.000383 & 0.408227 & -0.145087 & 0.735129 & -0.172964 & 0.296024 \\
\hline ADVDEC & 0.362931 & -0.389313 & 0.001496 & 0.839300 & 0.019941 & 0.030050 & -0.104828 \\
\hline BIDASKD & 0.378271 & 0.498471 & -0.201241 & 0.084651 & -0.197549 & -0.714051 & -0.108992 \\
\hline BIDASKP & 0.389579 & 0.303176 & -0.455986 & 0.026983 & -0.061223 & 0.481388 & 0.558729 \\
\hline BIDASKE & 0.406842 & 0.223148 & 0.001785 & -0.183737 & 0.143948 & 0.422564 & -0.742725 \\
\hline TSIR & -0.331138 & 0.671054 & 0.439138 & 0.449587 & 0.055331 & 0.201826 & 0.035613 \\
\hline
\end{tabular}

Source: Authors' estimations

Data source: South African Reserve Bank

Table A2: Descriptive statistics - Sentiment proxies

\begin{tabular}{|l|c|c|c|c|c|c|c|}
\hline & TURN & EQUITY & ADVDEC & BIDASKD & BIDASKP & BIDASKE & TSIR \\
\hline Mean & $1.58 \mathrm{E}+08$ & $1.93 \mathrm{E}+11$ & $4.77 \mathrm{E}+09$ & 8.141111 & 12.86218 & 9.741364 & 10.45709 \\
\hline Median & $1.53 \mathrm{E}+08$ & $1.81 \mathrm{E}+11$ & $5.10 \mathrm{E}+09$ & 7.503800 & 12.43370 & 9.552800 & 9.100000 \\
\hline Maximum & $4.84 \mathrm{E}+08$ & $6.13 \mathrm{E}+11$ & $1.06 \mathrm{E}+10$ & 16.38010 & 23.60340 & 17.79430 & 18.30000 \\
\hline Minimum & 59314111 & $3.88 \mathrm{E}+09$ & $2.94 \mathrm{E}+08$ & 3.538000 & 5.570200 & 4.376300 & 7.000000 \\
\hline Std. Dev. & 65178588 & $1.59 \mathrm{E}+11$ & $2.03 \mathrm{E}+09$ & 2.879800 & 3.797095 & 3.368032 & 2.918130 \\
\hline Skewness & 0.829223 & 0.536906 & -0.400795 & 0.702783 & 0.199852 & 0.377768 & 0.931927 \\
\hline Kurtosis & 4.419062 & 2.169577 & 2.979804 & 2.865390 & 2.793267 & 2.176221 & 2.414332 \\
\hline Jarque-Bera & 55.97914 & 21.65142 & 7.554719 & 23.42637 & 2.379388 & 14.68099 & 44.84925 \\
\hline Probability & 0.000000 & 0.000020 & 0.022883 & 0.000008 & 0.304314 & 0.000649 & 0.000000 \\
\hline Sum & $4.46 \mathrm{E}+10$ & $5.44 \mathrm{E}+13$ & $1.34 \mathrm{E}+12$ & 2295.793 & 3627.134 & 2747.065 & 2948.900 \\
\hline Sum Sq. Dev. & $1.19 \mathrm{E}+18$ & $7.10 \mathrm{E}+24$ & $1.16 \mathrm{E}+21$ & 2330.403 & 4051.438 & 3187.562 & 2392.851 \\
\hline Observations & 282 & 282 & 282 & 282 & 282 & 282 & 282 \\
\hline
\end{tabular}

Source: Authors' estimations

Data source: South African Reserve Bank 
Table A3: Descriptive statistics - Dependent and independent variables

\begin{tabular}{|l|c|c|c|c|c|c|c|}
\hline & NFPS & NFPB & INVSENT & MANUF & ALSIR & RDEX & INTSR \\
\hline Mean & $9,74 \mathrm{E}+08$ & $-7,41 \mathrm{E}+07$ & $-5,04 \mathrm{E}-16$ & 93,05355 & 0,009217 & 8,141111 & 6,295638 \\
\hline Median & $1,34 \mathrm{E}+09$ & $2,94 \mathrm{E}+08$ & 0,38 & 94,60 & 0,02 & 7,50 & 5,955 \\
\hline Maximum & $3,06 \mathrm{E}+10$ & $2,13 \mathrm{E}+10$ & 5,87 & 109,90 & 0,12 & 16,38 & 17,06 \\
\hline Minimum & $-2,82 \mathrm{E}+10$ & $-3,14 \mathrm{E}+10$ & $-5,02$ & 75,60 & 0,20 & 3,54 & 1,65 \\
\hline Std, Dev, & $6,70 \mathrm{E}+09$ & $7,19 \mathrm{E}+09$ & 2,87 & 8,19 & 0,04 & 2,88 & 3,002347 \\
\hline Skewness & 0,84 & 0,58 & 0,07 & 0,33 & $-1,05$ & 0,70 & 1,121562 \\
\hline Kurtosis & 7,19 & 5,68 & 2,11 & 2,03 & 6,30 & 2,87 & 4,162394 \\
\hline J-B & 239,86 & 99,77 & 9,49 & 16,23 & 180,42 & 23,43 & 74,99752 \\
\hline Prob. & 0,00 & 0,00 & 0,01 & 0,00 & 0,00 & 0,00 & 0,00 \\
\hline Sum & $2,75 \mathrm{E}+11$ & $-2,09 \mathrm{E}+10$ & 0,00 & 26241,10 & 2,60 & 2295,79 & 1775,37 \\
\hline Observ. & 282 & 282 & 282 & 282 & 282 & 282 & 282 \\
\hline
\end{tabular}

Source: Authors' estimations

Data source: South African Reserve Bank 